\title{
Spatial Characteristics of Claypan Soil Properties in an Agricultural Field
}

\author{
W. K. Jung, N. R. Kitchen,* K. A. Sudduth, and S. H. Anderson
}

\begin{abstract}
Spatial variability in soil properties has long been observed within uniformly managed fields. Understanding the spatial characteristics of soil properties would be helpful in understanding soil-landscape relationships and in the development of site-specific management. The primary objective of this research was to quantify the spatial characteristics of claypan soil properties for a 4-ha agricultural field located in north-central Missouri. Soil samples were collected in 2002 at three depths $(0-7.5,7.5-15$, and 15-30 cm) on a 30-m grid. Samples were analyzed for physical, chemical, and microbiological properties. Handheld and mobile apparent soil-profile electrical conductivity $\left(E C_{a}\right)$ values were also obtained. Spatial dependence was not identified for many properties. Yet, at a separation distance of $\sim \mathbf{4 0} \mathrm{m}$, clay and silt content, cation exchange capacity, and Bray-1 $P$ were spatially autocorrelated for the $15-$ to $30-\mathrm{cm}$ depth. Soil $\mathrm{EC}_{\mathrm{a}}$ showed a similar spatial autocorrelation. Spatial variations in most soil properties were better estimated by cross-semivariance analysis with $\mathbf{E C}_{\mathbf{a}}$ as a secondary variable than by simple semivariance analysis. Clay content was lowest and mostly homogeneous at the $0-$ to $7.5-\mathrm{cm}$ depth (mean $\left.=170 \mathrm{~g} \mathrm{~kg}^{-1}, \mathrm{SD}=\mathbf{2 . 0}\right)$, and highest and most variable at the 15- to 30 -cm depth $\left(\right.$ mean $\left.=410 \mathrm{~g} \mathrm{~kg}^{-1}, \mathrm{SD}=15.8\right)$. Thus, the spatial characteristics of soil texture and related soil properties varied greatly by depth and landscape position, probably the result of an uneven distribution of topsoil caused by tillage-accelerated water erosion. We conclude that characterizing the variation in the depth of the claypan horizon is a helpful step in describing other properties for these soils.
\end{abstract}

$I^{\top}$ N UNIFORMLY managed crop production fields, soil characteristics are commonly observed to have significant within-field variability (Cline, 1944). The predominant variability of a soil is determined by the cumulative effect of natural factors involved in its formation, including climate, topography, parent material, biological activity, and time (Jenny, 1941). Crop management practices also contribute to the spatial heterogeneity of some soil properties, beyond that attributable to natural processes (Cambardella and Karlen, 1999). Thus, soils under agricultural management are highly variable in chemical and physical characteristics. Due to within-field variation, uniform management of fields often results in overapplication of inputs in low-yielding areas and underapplica-

W.K. Jung and S.H. Anderson, Dep. of Soil, Environmental, and Atmospheric Sciences, Univ. of Missouri-Columbia, Columbia, MO 65211; N.R. Kitchen and K.A. Sudduth, USDA-ARS, Cropping Systems and Water Quality Research Unit, Univ. of Missouri-Columbia, Columbia, MO 65211; W.K. Jung, currently at Soil Management Division, National Institute of Agriculture and Technology, 249 Sudun-dong, Suwon-si, Kyunggi-do, Seoul, Korea, 441-707. Mention of trade names or commercial products is solely for the purpose of providing specific information and does not imply recommendation or endorsement by the U.S. Department of Agriculture. Received 17 Aug. 2005. *Corresponding author (KitchenN@missouri.edu).

Published in Soil Sci. Soc. Am. J. 70:1387-1397 (2006).

Soil \& Water Management \& Conservation

doi:10.2136/sssaj2005.0273

(c) Soil Science Society of America

677 S. Segoe Rd., Madison, WI 53711 USA tion of inputs in high-yielding areas (Davis et al., 1996; and Ferguson et al., 2002). This is a reason for considering spatial variability of soil properties in management decisions, with the potential result being more productive and efficient crop management systems. Site-specific management of soils and crops based on varying conditions within a field provides optimal management (Larson and Robert, 1991). Numerous research efforts have been aimed at comparing spatially variable soil characteristics to spatially variable crop yields to develop site-specific management practices (Cahn et al., 1994; Lund et al., 1999; Drummond et al., 2003; Eghball et al., 2003; Kitchen et al., 2003; Chang et al., 2004).

Quantifying spatial characteristics of soil properties, particularly when these properties are related to specific soil functions (e.g., crop production or water quality), can help improve understanding of soil-landscape processes and formulation of site-specific management; however, intensive grid soil sampling and subsequent laboratory analysis and interpolation for mapping such properties is most often impractical because of time and expense. These issues are less of a concern when sensors are employed to gather spatial information about soil and field characteristics. For example, a sensor technology commonly used for assessing soil variation is $\mathrm{EC}_{\mathrm{a}}$. Soil $\mathrm{EC}_{\mathrm{a}}$ can depend on various soil properties, including soil water content, soil salinity, cation exchange capacity (Rhoades et al., 1999; Corwin and Lesch, 2005), soil particle-size distribution (Sudduth et al., 2003; Jung et al., 2005), topsoil depth (Doolittle et al., 1994), and management practices (Johnson et al., 2001, 2003).

Whether soil properties are assessed through soil sampling or sensors, geostatistical techniques play an important role in the quantitative evaluation of spatial variability within a field. Classical experimental design statistics assumes that the data are independent from each other. If sampled data severely violate this assumption, incorrect conclusions may be made. Because results from field sampling are often spatially dependent, sampled data often violate the independence assumption. The correlation structure of a measurement in space (autocorrelation) provides insight into its spatial structure and describes how it changes in space in relation to the sampling frequency (Kravchenko, 2003). Spatial autocorrelation can also significantly influence interpretation. Descriptions of how spatial relationships change with distance of separation between measurement points are accomplished with tools such as the semivariogram and correlogram.

Interpolation techniques widely used to estimate variability patterns of soil properties are kriging and cokriging. Kriging is a geostatistical interpolation tech-

Abbreviations: CEC, cation exchange capacity; $\mathrm{EC}_{\mathrm{a}}$, apparent profile electrical conductivity; SOM, soil organic matter; TN, total nitrogen. 
nique that uses statistical properties of measured points (Isaacks and Srivastava, 1989). Cokriging uses one or more secondary variables to interpolate and accounts for spatial cross-correlation between the primary and secondary variable (Goovaerts, 1998). Cokriging can produce much more accurate and reliable estimation results than can the semivariance analysis technique (Kravchenko et al., 2002). A major disadvantage of geostatistical interpolation of soil properties is the need for a large number of soil samples that must be collected and analyzed for valid representation of the unsampled area. The economic impracticality of intensive soil sampling is one reason the idea of measuring spatial variability with sensors is appealing to producers (Kitchen et al., 2002), as it meets the need of having spatially dense measurements at a low cost.

Claypan soils, common in northeast Missouri and southern Illinois, have a restrictive high-clay subsoil layer usually occurring 20 to $40 \mathrm{~cm}$ below the soil surface. Claypans create a unique hydrology, characterized by slow water flow in the soil matrix of the restrictive clay layer. A better understanding of the spatial characteristics of claypan soil properties would be desirable when managing these soils, which are sensitive to soil degradation (e.g., runoff and erosion; Nikiforoff and Drosdoff, 1943; Kitchen et al., 1998), have high variability in crop productivity (Kitchen et al., 2005), and which frequently contribute to water quality impairment (Lerch et al., 2005). The claypan also has a large effect on plant root development (Wang et al., 2002). Clay content in the argillic horizon is generally $>40 \%$ and is comprised of smectitic (high shrink-swell) clay minerals. Depth to the argillic horizon (or topsoil depth) of claypan soils has been proposed as an important soil quality indicator (Kitchen et al., 1999). Lerch et al. (2005) estimated topsoil losses using GIS (geographic information system) models and found spatial variance of topsoil losses within a field as a result of long-term management practices. In a previous study, claypan soil properties were related to soil $\mathrm{EC}_{\mathrm{a}}$, but the spatial characteristics of these properties were not evaluated (Jung et al., 2005).

We hypothesized that similar spatial relationships exist among claypan soil properties, and that descriptions of the spatial characteristics of these properties would be helpful in understanding soil-landscape relationships and in considering site-specific soil management options. The objectives of this study were to: (i) quantify the spatial characteristics of soil properties for an agricultural claypan soil field, and (ii) evaluate if the description of spatial variation in soil properties could be improved by cokriging with soil $\mathrm{EC}_{\mathrm{a}}$.

\section{MATERIALS AND METHODS}

\section{Study Site}

A 4-ha study site (Fig. 1), located $3 \mathrm{~km}$ north of Centralia in central Missouri $\left(39^{\circ} 13^{\prime} 48^{\prime \prime} \mathrm{N}, 92^{\circ} 07^{\prime} 00^{\prime \prime} \mathrm{W}\right)$ was selected from a 35-ha research field. Mean annual temperature is $\sim 12^{\circ} \mathrm{C}$, and mean annual precipitation is $1004 \mathrm{~mm}$. An Order 1 soil survey (1:5000 scale) conducted in 1993 described the soil series of the study site as Adco (fine, smectitic, mesic Vertic Albaqualf) and Mexico (fine, smectitic, mesic Aeric Vertic Epiaqualf), as documented previously (Fraisse et al., 2001). These soils are formed in loess or a combination of loess and pedisediment and are poorly drained. They usually occur in upland areas with slopes varying from 0 to $5 \%$. Surface soil texture ranges from silt loam to silty clay loam. The subsoil claypan horizons consist of silty clay loam, silty clay, or clay (NRCS, 1995). Within the study site, the topsoil thickness above the claypan $\left(\mathrm{B}_{\mathrm{t}}\right.$ horizon) ranges from $10 \mathrm{~cm}$ to $>100 \mathrm{~cm}$. This site has been managed in a corn (Zea mays L.)-soybean [Glycine max (L.) Merr.] crop rotation under mulch tillage (i.e., crop residues are generally left on the surface after tillage operations) since 1991 and has experienced significant topsoil loss from water erosion as a result of $\sim 150 \mathrm{yr}$ of agricultural practices (Lerch et al., 2005).
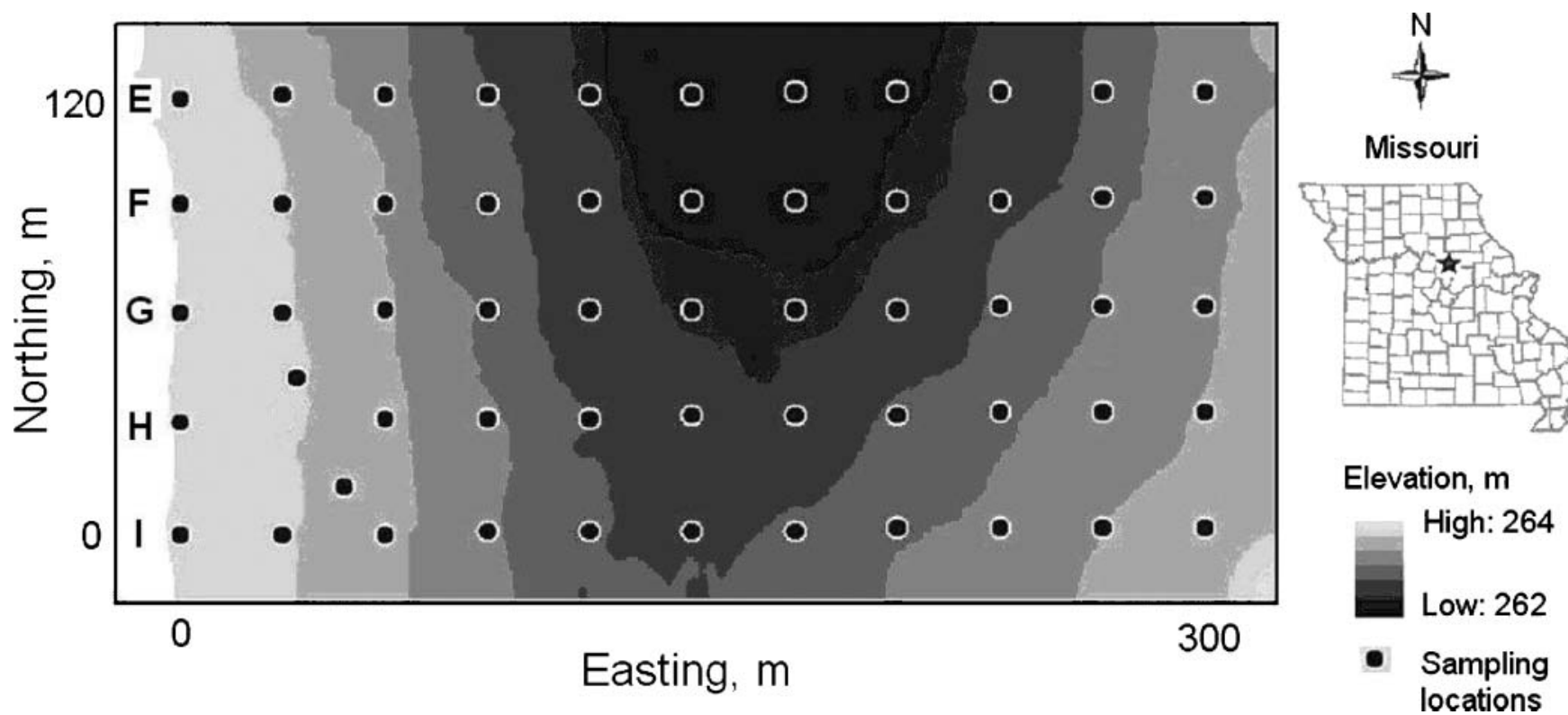

Fig. 1. Research site and sampling design (dotted lines represent sampling transects $\mathbf{E}$ and $\mathbf{H}$, which were selected to illustrate topsoil variation in Fig. 9). 


\section{Measurements and Analysis}

Soil samples were collected in June 2002 at three soil depths, 0 to $7.5,7.5$ to 15 , and 15 to $30 \mathrm{~cm}$, using a $30-\mathrm{m}$ grid sampling design $(n=55$; Fig. 1$)$. A real-time kinematic GPS (global positioning system) survey (accuracy $2-5 \mathrm{~cm}$ ) was used to identify sampling locations. Three soil cores $(5.5-\mathrm{cm}$ diameter) were taken by a hydraulic soil core sampler at each sampling site and were appropriately prepared for physical, chemical, and microbiological analysis. One extra soil core from each site was taken to a depth of $100 \mathrm{~cm}$ for visually identifying the claypan $\left(\mathrm{B}_{\mathrm{t}}\right.$ horizon) depth. Physical properties measured included soil particle size fraction (pipette method) and soil bulk density $\left(D_{\mathrm{b}}\right)$ following accepted methods (National Soil Survey Center Staff, 1996). Measured chemical properties consisted of CEC (cation exchange capacity) by the sum of cations $\left(1 \mathrm{MNH}_{4} \mathrm{OAc}\right.$ extractable at $\mathrm{pH} 7.0$ ), SOC (soil organic carbon, pretreated to remove carbonates when necessary; dry combustion, LECO, St. Joseph, MI), TN (total nitrogen, dry combustion, LECO, St. Joseph, MI) and P by the Bray-1 extraction method (Olsen and Sommers, 1982). Samples from the shallowest soil depth $(0-7.5 \mathrm{~cm})$ were used to determine aggregate stability, soil enzyme activity using the dehydrogenase method (Casida et al., 1964), and microbial biomass $\mathrm{C}$ as respired $\mathrm{CO}_{2}-\mathrm{C}$ using a 3-wk soil fumigation-incubation method (Johnson et al., 1994).

Soil $\mathrm{EC}_{\mathrm{a}}$ data $(n=55)$ were obtained at each location concurrent with soil sampling using a Geonics EM38 (Geonics Ltd., Mississauga, ON, Canada) instrument. The EM38 was operated in horizontal dipole mode at the soil surface, which provided an effective measurement depth of $\sim 0.75 \mathrm{~m}$. In this mode, sensitivity of the sensor is greatest nearest the sensor (i.e., at the soil surface) and declines exponentially with increasing soil depth (McNeill, 1992). Given this, the sensor will be, on average, twice as responsive to soil properties in the surface $30 \mathrm{~cm}$ of soil (i.e., the sampling depth of this study) than soil below $30 \mathrm{~cm}$. Soil $\mathrm{EC}_{\mathrm{a}}$ data were also obtained from a mobile $\mathrm{EC}_{\mathrm{a}}$ survey (EM38 operated in vertical mode with $\sim 1.5$-m effective depth) conducted on this field in 1999. Mobile $\mathrm{EC}_{\mathrm{a}}$ data on an approximate 10 -m grid (error $<2 \mathrm{~m}$ ) were extracted and used for this analysis $(n=399)$. Procedures for mobile EM38 operations and measurement depths, along with a detailed description of the 1999 data collection, are given in Sudduth et al. (2003).

\section{Geostatistical Data Analysis}

Measurements were assessed for spatial autocorrelation among neighboring observations of a variable, $X$, using Moran's I (Moran, 1948; Boots and Getis, 1988). Moran's I was computed by dividing the spatial covariance by the total variance according to

$$
I=\frac{n \sum \sum Z_{i} Z_{j}}{\sum Z_{i}^{2}}
$$

where $n=$ number of localities in an interval class, $Z_{i}=X_{i}-$ mean $X$, and $Z_{j}=X_{j}-$ mean $X$. Spatial autocorrelation is the relationship among values of a single variable that comes from the geographic arrangement of the areas in which these values occur. It measures the similarity of objects within an area or the degree to which a spatial phenomenon is correlated to itself in space (Cliff and Ord, 1973, 1981). Moran's $I$ was determined using a 150-m active lag distance (which is half of the research site length), a 30-m first lag distance, and a 15-m lag interval (GS + software, Version 5.1, Plainwell, MI). The average number of sample pairs per distance class was 102 and ranged from 52 to 184 , above the minimum standard of 30 pairs recommended by Legendre and Fortin (1989). Moran's $I$ values range from -1 to 1 . A positive value represents positive spatial autocorrelation and a negative value represents negative spatial autocorrelation. Following Snedecor and Cochran (1989) and Lauzon et al. (2005), we concluded significant spatial autocorrelation when the absolute value of Moran's $I$ was $>0.3$.

Geostatistics provided a tool for interpolation of unsampled locations, taking into account the spatial correlation of paired samples based on semivariance (Cliff and Ord, 1973). The sample semivariogram, $\gamma(h)$ is commonly used to estimate the structure of the spatial variation of a variable $V$. Semivariance is defined as

$$
\gamma(h)=\frac{1}{2 n(h)} \sum[V(s)-V(s+h)]^{2}
$$

where $V(s)$ and $V(s+h)$ are the observed values of $V$ at location $s$ and $s+h$, respectively, $h$ is the separation distance, and $n(h)$ is the number of paired comparisons at the distance $h$. The range is the separation distance beyond which two observations are independent of each other. The sill is the semivariogram value corresponding to the range. The discontinuity at the origin is called the nugget effect and arises from a combination of random errors and sources of variation at distances smaller than the shortest sampling interval (Goovaerts, 1998).

Isotropic semivariogram models were fitted to the soil properties. Lag-specific isotropic semivariogram models (i.e., maximum lag distance $=150 \mathrm{~m}$, first lag distance $=30 \mathrm{~m}$, and lag distance interval $=15 \mathrm{~m}$ ) were calculated and compared on the basis of range, sill, and nugget among spherical, exponential, linear, and Gaussian models. Only the best model based on $R^{2}$ was reported. We assumed a property to have significant spatial dependency when the spatial range was less than the maximum lag distance, the model $R^{2}$ was $>0.5$, and the proportion of the non-nugget spatially dependent variability was $>0.5$. Maps of soil properties were created by the block kriging interpolation method for each sampling depth.

To investigate the possibility of using sensor data to improve estimates of soil properties, isotropic cross-semivariogram models were also fit to the measured soil properties, using soil $\mathrm{EC}_{\mathrm{a}}$ from either handheld or mobile readings as the secondary variable. Model parameters and significance were as defined above for ordinary semivariogram models.

\section{RESULTS AND DISCUSSION Frequency Distribution of Soil Properties}

Frequency distributions of the soil properties were different by soil depth (Fig. 2). Soil bulk density values were lower at the $0-$ to $7.5-\mathrm{cm}$ depth due to tillage operations and consequent mixing of crop residue with topsoil. Clay and silt contents and CEC for the upper two soil depths $(0-7.5$ and $7.5-15 \mathrm{~cm})$ were notably different than the 15- to 30-cm soil depth. Distribution of clay content and CEC were very similar and unimodal at the two shallow soil depths and multimodal at the third soil depth. High clay content and CEC at this depth were clearly the result of sampling in the claypan $\left(\mathrm{B}_{\mathrm{t}}\right.$ horizon). Low clay content and CEC at this depth indicated that sampling excluded the claypan, and that the claypan was apparently deeper within the profile.

Soil organic C and TN were highest near the surface and intermediate in the deepest sampling depth. Several explanations are possible for this observation. Previous studies have shown that plant residues (e.g., quantity 
and quality of sources) affect $\mathrm{C}$ sequestration rates in soil (Allison, 1973). Soil organic matter decomposition is relatively dynamic at the shallow soil depth because of soil disturbance from annual tillage practices, plant residue inputs, and chemical fertilization. While not measured, the SOM (soil organic matter) turnover in the 15- to 30-cm depth may be slow because it is more stable from decomposition. Also, the slightly higher SOC and TN at the $15-$ to $30-\mathrm{cm}$ depth than at the $7.5-$ to $15-\mathrm{cm}$ depth may be attributed to an increase in crop root growth at the deeper depth in response to the morphological characteristics of the claypan (argillic horizon). Others have documented that the claypan can stimulate root growth (Wang et al., 2002; Myers, 2005). Bray-1 P was higher and more variable for the shallowest soil depth (i.e., 0-7.5 cm), presumably an effect of fertilization and plant residues. We conclude that significant vertical spatial variation of many soil properties (i.e., variability among sampling depths) exists on this site. Further, we assert that variation in clay content is the primary driving factor causing vertical spatial variation for many of the other soil properties measured like $\mathrm{EC}_{\mathrm{a}}$ or CEC (discussed below).

Soil aggregate stability (Fig. 2) and microbial properties (not shown) were also highly variable and generally exhibited multimodal distributions. Soil $\mathrm{EC}_{\mathrm{a}}$ was normally distributed for both the 2002 handheld and the 1999 mobile $\mathrm{EC}_{\mathrm{a}}$ readings (Fig. 2). Handheld $\mathrm{EC}_{\mathrm{a}}$ was positively correlated to coincident (within $\sim 2 \mathrm{~m}$ ) mobile $\mathrm{EC}_{\mathrm{a}}$ measurements (Fig. 3). The mean handheld $\mathrm{EC}_{\mathrm{a}}$ reading $\left(47 \mathrm{mS} \mathrm{m}^{-1}\right)$ was slightly higher than the mean mobile $\mathrm{EC}_{\mathrm{a}}$ reading $\left(41 \mathrm{mS} \mathrm{m}^{-1}\right)$. Factors potentially contributing to this difference included the handheld $\mathrm{EC}_{\mathrm{a}}$ reading being closer to the soil surface than the mobile $\mathrm{EC}_{\mathrm{a}}$ reading, soil moisture differences at the time the measurements were taken, and the differences in weighting factors and effective measurement depths between horizontal mode (handheld) measurements and vertical mode (mobile) measurements (Sudduth et al., 2001).
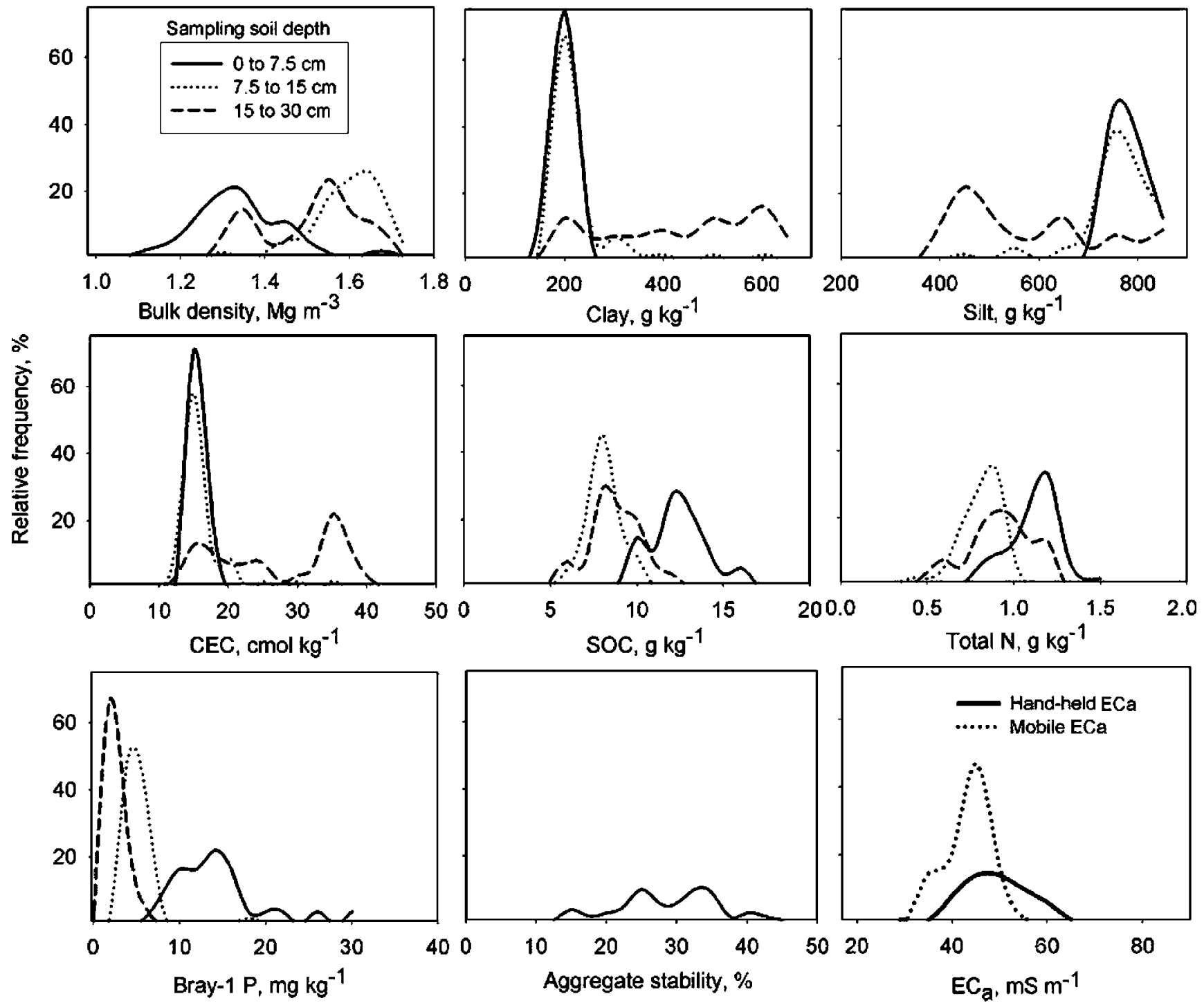

Fig. 2. Frequency distributions of soil properties by soil depth. Soil $\mathbf{E C}_{\mathbf{a}}$ (apparent profile electrical conductivity) was measured using two methods and aggregate stability was only measured for the surface depth at each location. $\mathrm{CEC}=$ cation exchange capacity; SOC $=$ soil organic carbon. 


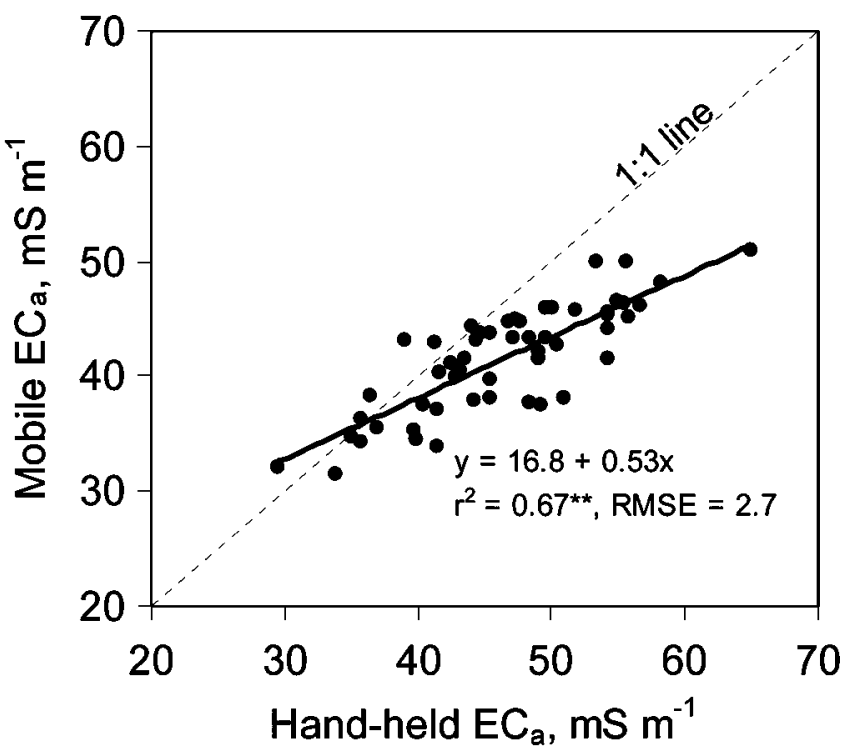

Fig. 3. Relationship between handheld and mobile $\mathbf{E C}_{\mathbf{a}}$ (apparent profile electrical conductivity) readings.

\section{Autocorrelation of Soil Properties}

Spatial autocorrelations of soil properties were calculated from grid points at $15-\mathrm{m}$ lag intervals (Fig. 4 and 5). For many properties and soil sampling depths, spatial autocorrelations were positive at a separation distance $<50 \mathrm{~m}$; however, significant spatial autocor- relation $(|I|>0.3)$ was generally only found at the lower end of separation distances for which calculations could be made. This implies that we would have lost our ability to determine spatial structure for these soil properties had sampling spacing been $>50 \mathrm{~m}$. As examples, spatial correlations of soil texture at the shallowest sampling depth were highest and $>0.3$ at $\sim 40-\mathrm{m}$ separation distance. Spatial autocorrelation at the 15- to $30-\mathrm{cm}$ sampling depth for clay content, silt content, CEC, and Bray-1 P were also highest $(>0.3)$ at $\sim 40$-m separation distance. We assume that, at the 15-to 30-cm depth, intact undisturbed soil expressed inherent spatial characteristics. In contrast, surface soil has been disturbed from tillage-accelerated water erosion or deposition processes (Jamison et al., 1968), and thus exhibited less spatial structure. For a separation distance $>60 \mathrm{~m}$, spatial autocorrelation of most soil properties was generally neutral to slightly negative. Spatial autocorrelation of soil microbial properties and soil aggregate stability was consistently close to zero for all separation distances (Fig. 5). For these, our sampling strategy failed to identify spatial structure.

Spatial autocorrelation of $\mathrm{EC}_{\mathrm{a}}$ for both handheld and mobile readings was positive and $>0.3$ at the $<40-\mathrm{m}$ separation distance. At separation distances $>60 \mathrm{~m}$, spatial correlation of $\mathrm{EC}_{\mathrm{a}}$ generally remained close to zero.

Thus, the trend observed was positive spatial autocorrelation at short-range distances $(<50 \mathrm{~m})$ and little or no autocorrelation at greater distances. Overall, the

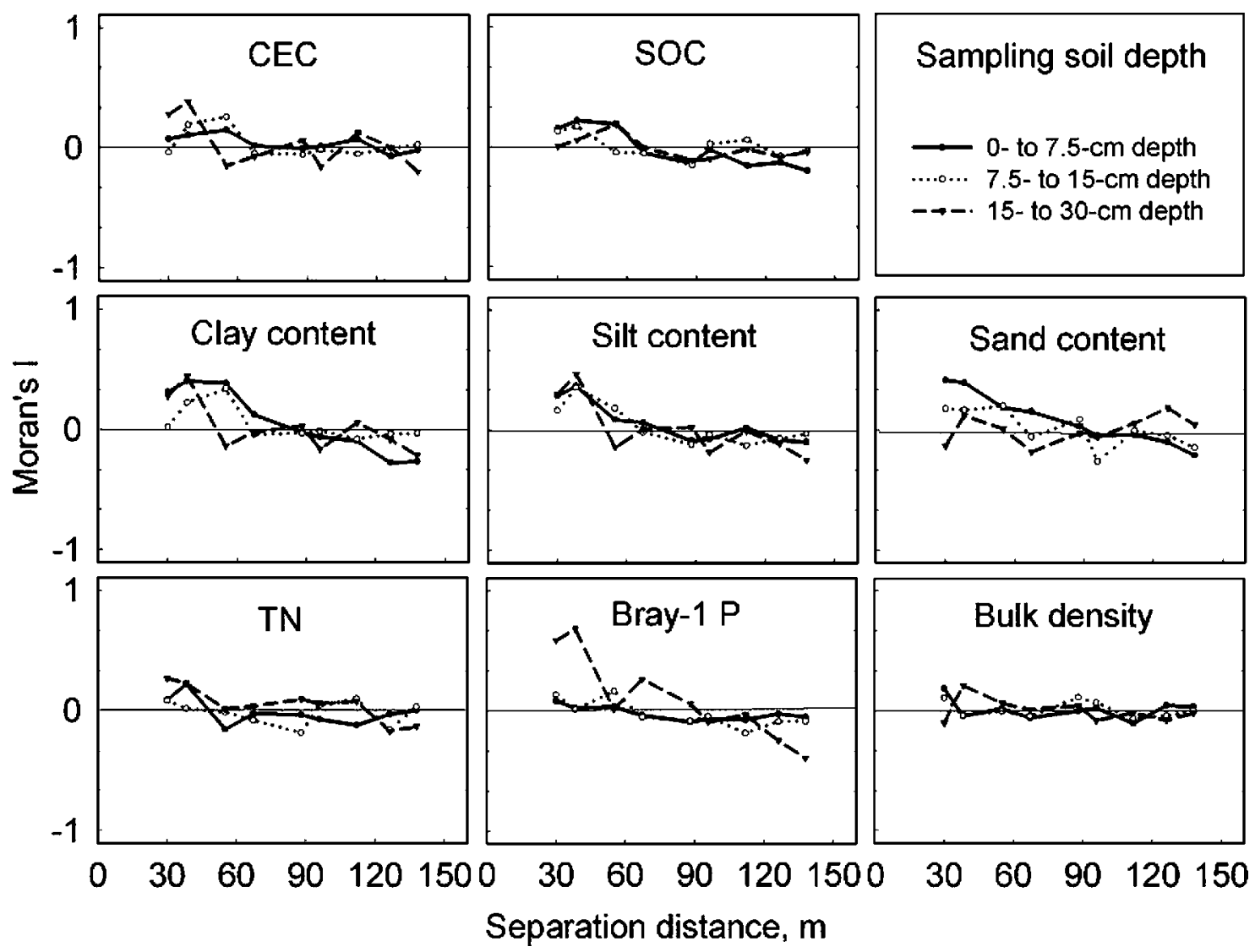

Fig. 4. Spatial autocorrelation (Moran's $I$ ) of soil physical and chemical properties by soil sampling depth. $\mathrm{CEC}=$ cation exchange capacity; $\mathrm{SOC}=$ soil organic carbon; $\mathbf{T N}=$ total nitrogen. 

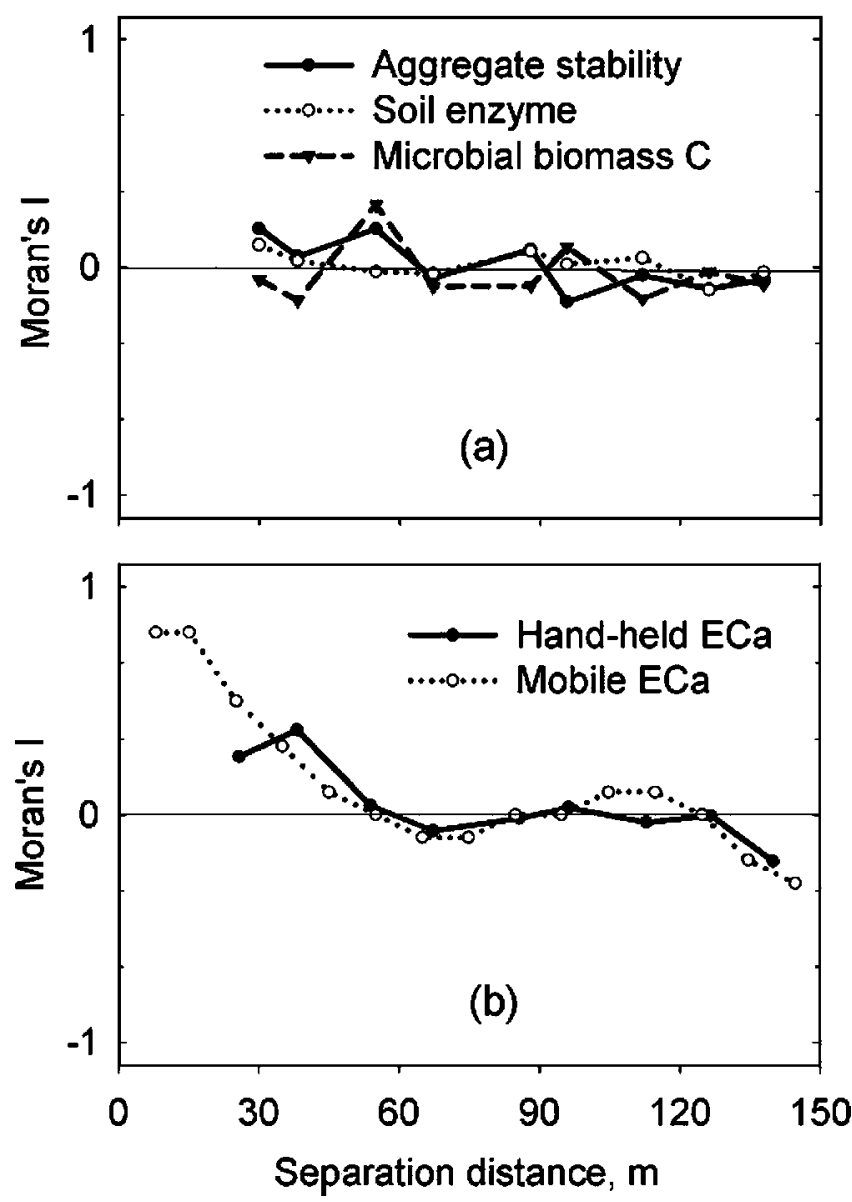

Fig. 5. Spatial autocorrelation (Moran's $I$ ) of (a) microbiological soil properties and aggregate stability for the 0 - to $7.5-\mathrm{cm}$ depth, and (b) soil $\mathrm{EC}_{\mathbf{a}}$ (apparent profile electrical conductivity).

similar patterns of spatial dependence indicate that soil formation and degradation processes affect these claypan soil properties in a similar manner.

\section{Semivariance Analysis of Soil Properties}

Several soil properties showed strong spatial dependence at the three sampling depths (Table 1). Ranges of spatial dependence from the semivariogram models were highly variable among properties, varying from 71 to $>150 \mathrm{~m}$. Clay and silt content showed a range of spatial dependence between 77 and $147 \mathrm{~m}$ at the shallowest and deepest soil sampling depths, but the range could not be determined at the intermediate sampling depth. Semivariance of CEC at the deep sampling depth was similar to silt and clay content. Soil $\mathrm{EC}_{\mathrm{a}}$ showed spatial dependency at a range similar to that of soil texture. The $\mathrm{EC}_{\mathrm{a}}$ was correlated with clay content at the subsurface soil depth. This result is reasonable because, on claypan soils, $\mathrm{EC}_{\mathrm{a}}$ is largely affected by depth to the argillic horizon (Sudduth et al., 2003). Soil organic C $(0-7.5 \mathrm{~cm})$ and Bray-1 P $(15-30 \mathrm{~cm})$ also showed spatial dependence. In other claypan soil investigations, soil $\mathrm{P}$ at the 15- to $30-\mathrm{cm}$ soil depth was found to be significantly correlated with soil $\mathrm{EC}_{\mathrm{a}}$ (Jung et al., 2005).

Semivariogram models for TN, aggregate stability, and microbiological properties generally did not show evidence of spatial dependence. Thus, if spatial dependence occurred with these properties, it must have occurred at either shorter $(<30-\mathrm{m})$ or longer $(>150-\mathrm{m})$ distances. Closer sampling locations (i.e., higher sampling density) would be needed to determine if spatial dependence occurred at shorter distances.

\section{Cross-Semivariance Analysis of Soil Properties}

To evaluate if soil $\mathrm{EC}_{\mathrm{a}}$ could be used to improve the understanding of spatial characteristics of soil properties, cross-semivariance analyses were performed using the handheld $\mathrm{EC}_{\mathrm{a}}$ readings (Table 2). Given the criteria we used to identify significant spatial structure, crosssemivariance with soil $\mathrm{EC}_{\mathrm{a}}$ enhanced detection of spatial structure. For example, at the shallowest soil depth,

Table 1. Parameters $\dagger$ of the semivariogram models $\ddagger$ for soil properties by soil sampling depth. Results are shown when range $\leq$ active lag distance and $R^{2}>0.5$. Aggregate stability, soil enzyme, and microbial biomass data were only obtained for the 0- to 7.5-cm soil depth. Soil EC $\mathrm{E}_{\mathrm{a}}$ (apparent profile electrical conductivity) is a soil profile measurement and is not associated with a specific soil depth.

\begin{tabular}{|c|c|c|c|c|c|c|c|c|c|c|c|c|c|c|c|c|c|c|}
\hline \multirow[b]{2}{*}{ Property } & \multicolumn{6}{|c|}{ 0- to $7.5-\mathrm{cm}$ soil depth } & \multicolumn{6}{|c|}{ 7.5- to $15-\mathrm{cm}$ soil depth } & \multicolumn{6}{|c|}{ 15- to 30-cm soil depth } \\
\hline & Model & $\mathbf{C}_{\mathbf{0}}$ & $\mathbf{C}_{\mathbf{0}}+\mathbf{C}$ & $\mathbf{A}_{0}$ & PSV & $R^{2}$ & Model & $\mathbf{C}_{\mathbf{0}}$ & $\mathbf{C}_{\mathbf{0}}+\mathbf{C}$ & $\mathbf{A}_{\mathbf{0}}$ & PSV & $R^{2}$ & Model & $\mathbf{C}_{\mathbf{0}}$ & $\mathbf{C}_{\mathbf{0}}+\mathbf{C}$ & $\mathbf{A}_{\mathbf{0}}$ & PSV & $R^{2}$ \\
\hline & & & & $\mathbf{m}$ & & & & & Soil prope & m & & & & & & $\mathbf{m}$ & & \\
\hline $\begin{array}{l}\text { Bulk density } \\
\text { Soil texture }\end{array}$ & & & & & & & & & & & & & & & & & & \\
\hline $\begin{array}{l}\text { Clay content } \\
\text { Silt content } \\
\text { Sand }\end{array}$ & $\begin{array}{l}\mathbf{G} \\
\mathbf{S} \\
\mathbf{G}\end{array}$ & $\begin{array}{l}213 \\
334 \\
469\end{array}$ & $\begin{array}{r}589 \\
1545 \\
1075\end{array}$ & $\begin{array}{r}147 \\
94 \\
134\end{array}$ & $\begin{array}{l}0.64 \\
0.78 \\
0.56\end{array}$ & $\begin{array}{l}0.93 \\
0.83 \\
0.95\end{array}$ & & & & & & & $\begin{array}{l}\mathbf{S} \\
\mathbf{S}\end{array}$ & $\begin{array}{l}1120 \\
1480\end{array}$ & $\begin{array}{l}26950 \\
23550\end{array}$ & $\begin{array}{l}77 \\
86\end{array}$ & $\begin{array}{l}0.96 \\
0.94\end{array}$ & $\begin{array}{l}0.65 \\
0.70\end{array}$ \\
\hline $\begin{array}{l}\text { Sand content } \\
\text { Cation exchange capacity } \\
\text { Soil organic C } \\
\text { Total N }\end{array}$ & $\mathbf{S}$ & 1.4 & 3.1 & 147 & 0.56 & 0.93 & $\mathbf{S}$ & 460 & 921 & 117 & 0.5 & 0.61 & $\mathbf{S}$ & 4.3 & 83 & 71 & 0.95 & 0.59 \\
\hline $\begin{array}{l}\text { Bray-1 P } \\
\text { Aggregate stability } \\
\text { Soil enzyme } \\
\text { Microbial biomass }\end{array}$ & & & & & & & $\begin{array}{l}- \\
\overline{-} \\
-\end{array}$ & $\begin{array}{l}- \\
-\end{array}$ & $\begin{array}{l}- \\
- \\
- \\
\text { Soil EC } \\
\end{array}$ & $\begin{array}{l}- \\
- \\
-\end{array}$ & $\begin{array}{l}- \\
-\end{array}$ & $\begin{array}{l}- \\
- \\
-\end{array}$ & $\begin{array}{l}\mathbf{G} \\
- \\
- \\
-\end{array}$ & $\begin{array}{l}0.6 \\
- \\
- \\
-\end{array}$ & $\begin{array}{l}2.3 \\
- \\
- \\
-\end{array}$ & $\begin{array}{l}144 \\
- \\
- \\
-\end{array}$ & $\begin{array}{l}0.74 \\
- \\
- \\
-\end{array}$ & $\begin{array}{l}\mathbf{0 . 8 5} \\
- \\
- \\
-\end{array}$ \\
\hline $\begin{array}{l}\text { Handheld EC } \\
\text { Mobile EC }_{\mathbf{a}}\end{array}$ & $\begin{array}{l}\mathbf{S} \\
\mathbf{S}\end{array}$ & $\begin{array}{l}20 \\
0.01\end{array}$ & $\begin{array}{l}\mathbf{5 3} \\
\mathbf{2 3 . 1}\end{array}$ & $\begin{array}{l}92 \\
80\end{array}$ & $\begin{array}{l}0.63 \\
0.99\end{array}$ & $\begin{array}{l}0.76 \\
0.90\end{array}$ & - & - & $\begin{array}{l}- \\
-\end{array}$ & - & - & - & - & - & - & - & - & - \\
\hline
\end{tabular}

$\dagger C_{0}=$ nugget; $C_{0}+C=$ sill; $A_{0}=$ range; $P S V=C /\left(C_{0}+C\right)$, which is the proportion of the non-nugget, spatially dependent variability as an indicator of degree of spatial structure: as the value approaches 1 , the spatial autocorrelation becomes stronger.

$\doteqdot G$ = gaussian, $S$ = spherical; for the gaussian model, $A_{0}$ is the effective spatial range, or the point where the model reaches $95 \%$ of the sill value. 
Table 2. Parameters $\dagger$ of the cross-semivariogram models $\ddagger$ for soil properties with handheld $\mathbf{E C}_{\mathrm{a}}$ (apparent profile electrical conductivity; $n=55$ ) as a covariate by soil sampling depth. Aggregate stability, soil enzyme, and microbial biomass data were only obtained for the 0to $7.5-\mathrm{cm}$ soil depth. Results are shown when range $\leq$ active lag distance and $R^{2}>0.5$.

\begin{tabular}{|c|c|c|c|c|c|c|c|c|c|c|c|c|c|c|c|c|c|c|}
\hline \multirow[b]{2}{*}{ Soil property } & \multicolumn{6}{|c|}{ 0- to $7.5-\mathrm{cm}$ soil depth } & \multicolumn{6}{|c|}{ 7.5- to 15 -cm soil depth } & \multicolumn{6}{|c|}{ 15- to $30-\mathrm{cm}$ soil depth } \\
\hline & Model & $\mathbf{C}_{0}$ & $\mathbf{C}_{\mathbf{0}}+\mathbf{C}$ & $\mathbf{A}_{0}$ & PSV & $R^{2}$ & Model & $\mathbf{C}_{0}$ & $\mathbf{C}_{\mathbf{0}}+\mathbf{C}$ & $\mathbf{A}_{0}$ & PSV & $R^{2}$ & Model & $\mathbf{C}_{\mathbf{0}}$ & $\mathbf{C}_{\mathbf{0}}+\mathbf{C}$ & $\mathbf{A}_{\mathbf{0}}$ & PSV & $R^{2}$ \\
\hline & & & & $\mathbf{m}$ & & & & & & $\mathbf{m}$ & & & & & & m & & \\
\hline $\begin{array}{l}\text { Bulk density } \\
\text { Soil texture }\end{array}$ & $\mathbf{S}$ & 0.04 & 0.56 & 65 & 0.93 & 0.66 & & & & & & & $\mathbf{G}$ & 0.35 & 0.71 & 110 & 0.50 & 0.67 \\
\hline Clay content & G & 53 & 124 & 134 & 0.57 & 0.91 & $\mathbf{S}$ & 94 & 339 & 88 & 0.72 & 0.55 & $\mathbf{S}$ & 184 & 1026 & 88 & 0.82 & 0.74 \\
\hline Silt content & $\mathbf{S}$ & 81 & 219 & 95 & 0.63 & 0.77 & $\mathbf{S}$ & 108 & 412 & 90 & 0.74 & 0.65 & $\mathbf{S}$ & 201 & 970 & 95 & 0.79 & 0.78 \\
\hline Sand content & $\mathbf{G}$ & 94 & 189 & 145 & 0.50 & 0.90 & $\mathbf{S}$ & 68 & 159 & 113 & 0.57 & 0.78 & & & & & & \\
\hline $\begin{array}{l}\text { Cation exchange } \\
\text { capacity }\end{array}$ & $\mathbf{G}$ & 3.1 & 6.2 & 104 & $\mathbf{0 . 5 0}$ & 0.90 & $\mathbf{S}$ & 2.2 & 4.4 & 70 & 0.5 & 0.51 & $\mathbf{S}$ & 9.7 & 57 & 79 & 0.83 & 0.68 \\
\hline Soil organic C & $\mathbf{S}$ & 2.5 & 9.1 & 134 & 0.73 & 0.93 & & & & & & & & & & & & \\
\hline Total N & $\mathbf{G}$ & 0.4 & 0.8 & 100 & 0.52 & 0.86 & & & & & & & & & & & & \\
\hline Bray-1 P & & & & & & & & & & & & & G & 2.9 & 8.6 & 122 & 0.67 & 0.85 \\
\hline Aggregate stability & $\mathbf{E}$ & 0.1 & 37.1 & 59 & 0.99 & 0.66 & - & - & - & - & - & - & - & - & - & - & - & - \\
\hline Soil enzyme & & & & & & & - & - & - & - & - & - & - & - & - & - & - & - \\
\hline Microbial biomass & & & & & & & - & - & - & - & - & - & - & - & - & - & - & - \\
\hline
\end{tabular}

$\dagger C_{0}=$ nugget; $C_{0}+C=$ sill; $A_{0}=$ range; PSV $=C /\left(C_{0}+C\right)$, which is the proportion of the non-nugget, spatially dependent variability as an indicator of degree of spatial structure: as the value approaches 1 , the spatial autocorrelation becomes stronger.

$\ddagger \mathbf{G}=$ gaussian, $\mathbf{S}=$ spherical, $\mathbf{E}=$ exponential. For the gaussian and exponential models, $\mathbf{A}_{\mathbf{0}}$ is the effective spatial range, or the point where the model reaches $95 \%$ of the sill value.

spatial dependency was found for CEC, TN, and aggregate stability (ranges of 59-104 m) when cross-semivariance was used, but not with ordinary semivariance analysis (Table 1).

A more spatially dense $\mathrm{EC}_{\mathrm{a}}$ dataset (mobile survey, $n=399$ ) was also used to estimate spatial characteristics of soil properties by cross-semivariance analysis. Similar to results for the handheld $\mathrm{EC}_{\mathrm{a}}$ survey, results for the mobile $\mathrm{EC}_{\mathrm{a}}$ survey improved spatial structure determination when compared with semivariance analysis (data not shown); however, no appreciable difference was found between cross-semivarigram results of the two different
Variable

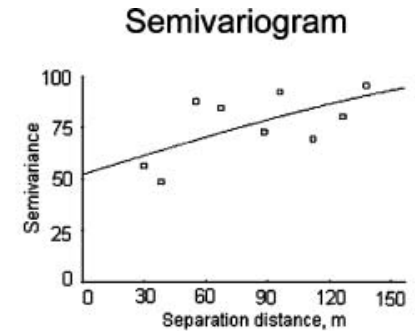

Cross-semivariogram

CEC-cokriged with hand-held $\mathrm{EC}_{\mathrm{a}}(\mathrm{n}=55)$

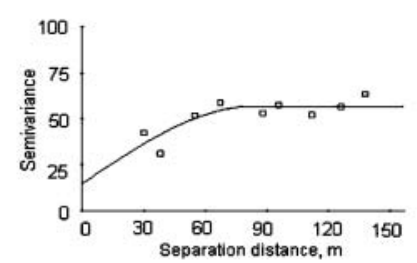

CEC-cokriged with mobile $\mathrm{EC}_{\mathrm{a}}$ $(n=399)$

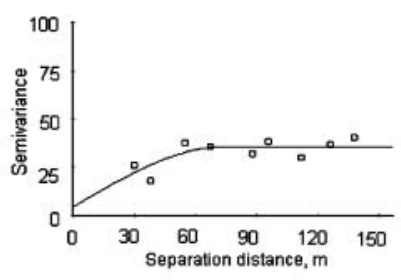

\section{Kriged map}

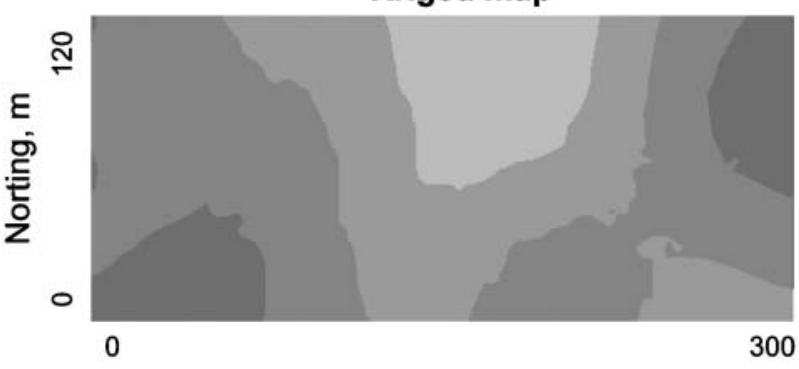

Easting,m

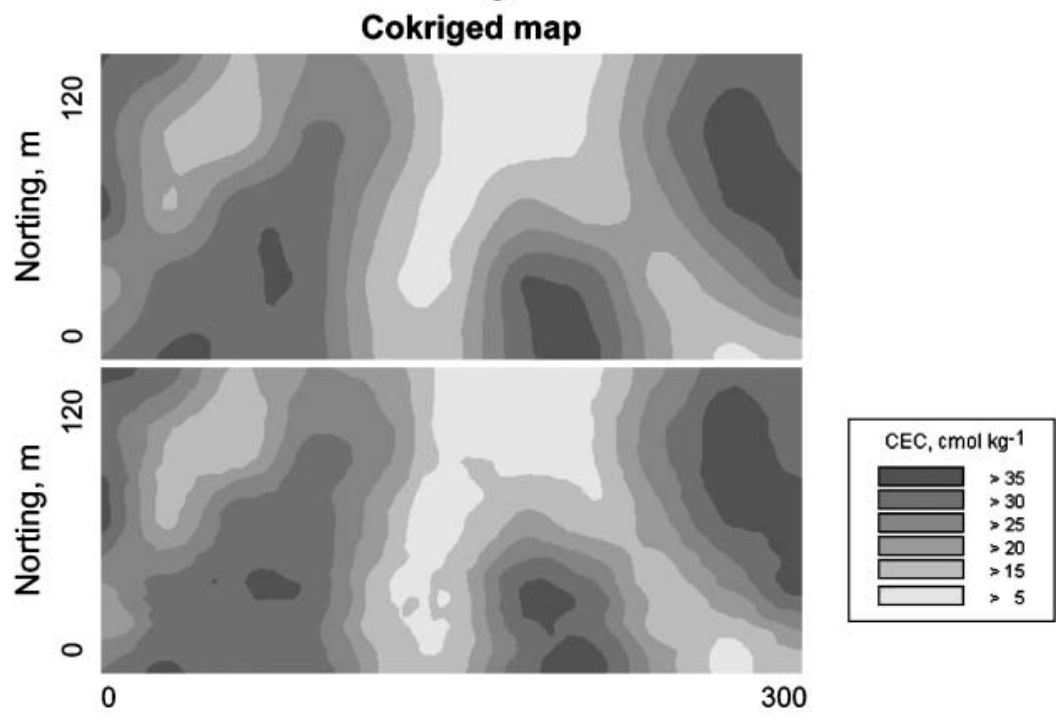

Easting, $\mathrm{m}$

Fig. 6. Interpolated maps of 15- to 30-cm CEC (cation exchange capacity) obtained by kriging and by cokriging with handheld EC $\mathrm{C}_{\mathrm{a}}$ (apparent profile electrical conductivity) and mobile $\mathrm{EC}_{\mathrm{a}}$ as a covariate. Mapped area is the same as that shown in Fig. 1. 
Soil depth

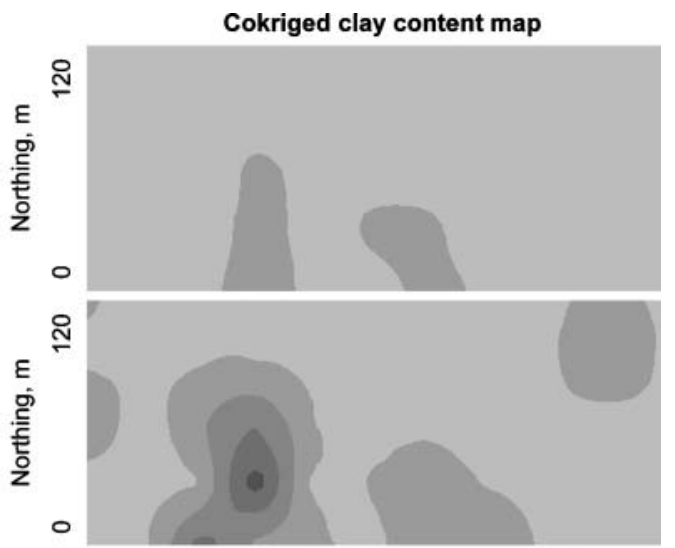

15 to $30 \mathrm{~cm}$

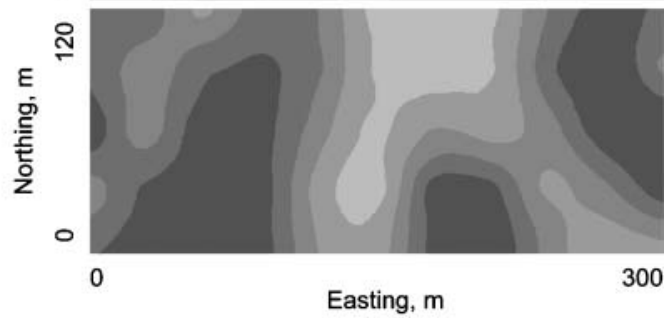

Clay content, $\mathrm{g} \mathrm{kg}-1$

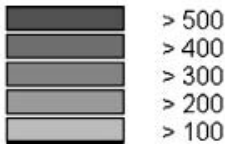

Fig. 7. Interpolated clay content maps for each sampling depth using cokriging with handheld soil $\mathbf{E C}_{\mathrm{a}}$ (apparent profile electrical conductivity; $n=55$ ) as a covariate. Mapped area is the same as that shown in Fig. 1.

$\mathrm{EC}_{\mathrm{a}}$ datasets, even though the mobile $\mathrm{EC}_{\mathrm{a}}$ dataset had more than seven times more readings. The power of secondary measurements in this case was not in improved accuracy when predicting the primary variable, but rather increased mapping resolution. Figure 6 shows an example of three interpolation results for CEC at the $15-$ to $30-\mathrm{cm}$ soil depth. Spatial detail was increased with cokriging compared with ordinary kriging, but map resolution was most detailed when the higher density mobile $\mathrm{EC}_{\mathrm{a}}$ measurements were used as the covariate.

Using the spatial structure from the cross-semivariogram with handheld $\mathrm{EC}_{\mathrm{a}}$ as a covariate, clay content was also mapped to show variation by soil depth (Fig. 7). At the 0- to $7.5-\mathrm{cm}$ soil depth, clay content was lowest of the three depths measured (mean $=170 \mathrm{~g} \mathrm{~kg}^{-1}, \mathrm{SD}$ $=2.0$ ) and more evenly distributed across the field than clay content at the other depths. At the $7.5-$ to $15-\mathrm{cm}$ soil depth, clay content increased (mean $=200 \mathrm{~g} \mathrm{~kg}^{-1}$, $\mathrm{SD}=7.4)$, and at the 15 - to $30-\mathrm{cm}$ soil depth, clay content was highest ( mean $=410 \mathrm{~g} \mathrm{~kg}^{-1}, \mathrm{SD}=15.8$ ), with obvious steep clay content gradients occurring between backslope and footslope areas of the field (Fig. 1). At the 15- to 30 -cm soil depth, high-clay-content areas $\left(>400 \mathrm{~g} \mathrm{~kg}^{-1}\right)$ were often found in summit and backslope positions (i.e., relatively high elevation), while low-clay-content areas $\left(<200 \mathrm{~g} \mathrm{~kg}^{-1}\right)$ were found in lower elevation footslope positions. Pedisediments in the footslope area from water erosion have effectively buried the higher clay content horizons to a depth below the sampling depth of this study. Semivariograms and kriged maps for both handheld and mobile $\mathrm{EC}_{\mathrm{a}}$ are shown in Fig. 8. An area of lower $\mathrm{EC}_{\mathrm{a}}$ in the middle part of the field was associated with low clay at the deep soil depth $(15-30 \mathrm{~cm})$. Soil $\mathrm{EC}_{\mathrm{a}}$ has previously been related to clay content in soil profiles (Sudduth et al., 2003). In this case and for this sampling depth, $\mathrm{EC}_{\mathrm{a}}$ could be used as a proxy for estimating spatial characteristics of clay content. Soil at the 15- to $30-\mathrm{cm}$ depth is generally below the soil profile subjected to cultivation, hence this soil has had little disturbance

\section{Variable}

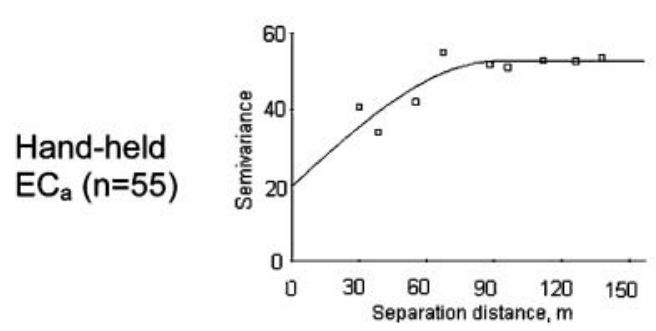

Mobile $\mathrm{EC}_{\mathrm{a}}$ $(n=399)$

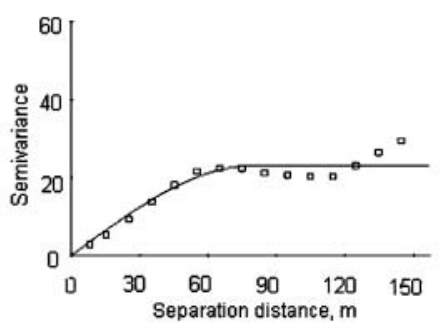

\section{Kriged $E_{a}$ map}
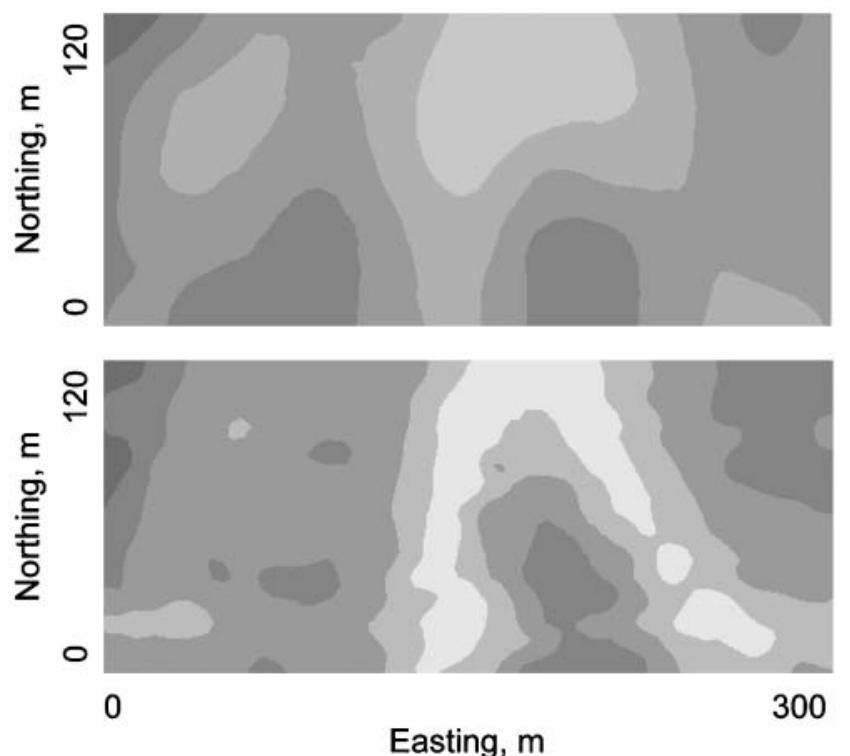

\section{Easting, $m$}

ECa, $\mathrm{ms} \mathrm{m}^{-1}$

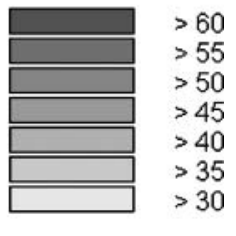

$>55$

$>50$

$>45$

$>35$

$>30$

Fig. 8. Semivariograms and kriged maps of handheld and mobile $\mathbf{E C}_{\mathbf{a}}$ (apparent profile electrical conductivity). Mapped area is the same as that shown in Fig. 1. 
by modern tillage practices. Furthermore, soil erosion and deposition processes mostly impact the surface soil. We recognize that our association exists primarily because the claypan has a dominant texture change expressed at the 15- to $30-\mathrm{cm}$ soil depth for most areas of the field.

This investigation illustrates a major challenge with spatial assessment of soil properties that have a distinct vertical spatial component. Further illustrating this, crosssections showing the soil surface, depth of topsoil over the argillic horizon and soil sampling depths are given in Fig. 9 for two east-west transects (transects identified in Fig. 1). This illustrates how a given sampling depth may either include or exclude a portion of the argillic horizon, depending on position in the landscape. Generally, soils with a deep claypan were found in the middle portion of the transects, in the lower elevation areas of the field. Here, soil sampling to $30 \mathrm{~cm}$ did not reach the claypan. In other areas, such as part of Transect $\mathrm{H}$, the claypan boundary was included in the $7.5-$ to $15-\mathrm{cm}$ soil sampling depth. Through much of the field, the claypan boundary was captured in the 15- to $30-\mathrm{cm}$ soil sampling depth. Previous erosion modeling for this field described topsoil movement from upland landscape positions to lower landscape positions (Lerch et al., 2005). Degraded claypan soils, like those present in this field, offer a special challenge
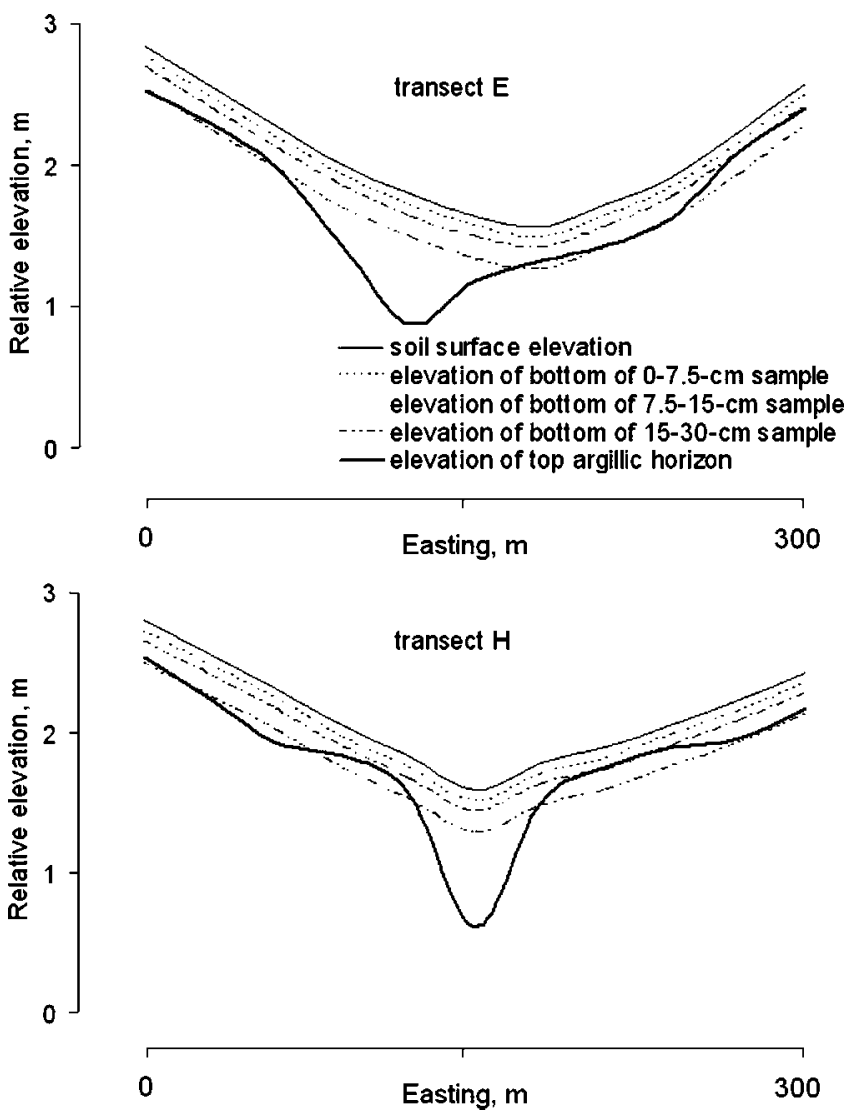

Fig. 9. Elevation of the soil surface, elevation of the bottom of the three sampling depths (dashed lines), and elevation of the top of the argillic horizon for two east-west transects (see transect locations on Fig. 1). This illustrates how a given sampling depth may either include or exclude a portion of the argillic horizon, depending on position in the landscape. when the soil morphology that is being sampled varies so dramatically. We propose that understanding the variation in a horizon that has such a pronounced effect on plant growth (Kitchen et al., 1999) and hydrology (Ghidey et al., 2005; Kitchen et al., 1998), i.e., the argillic horizon of claypan soils, is a critical step in characterizing the behavior of that soil. In turn, steps to improve site-specific management of these soils ought to consider how this varying horizon is related to other soil and landscape properties. For example, depth of the argillic horizon for these soils has been shown to be significantly related to subsoil fertility (Spautz, 1998) and potential fertilizer management. Also claypan topsoil depth corresponds with areas of fields vulnerable to sediment, nutrient, and herbicide losses with runoff (Lerch et al., 2005).

While assessing spatial characteristics of soil properties has recognized merit, major obstacles remain, limiting wide adoption of this concept by crop producers. As shown in this study, spatial variation within fields, both between locations and by soil depth, is one of those obstacles. Mapping of soil properties that have spatial structure at short-range spatial dependencies will require high-density sampling. This is generally cost and labor prohibitive for most producers, unless sensors can be employed to accurately and rapidly collect this information. To educate and convince land managers to use soil principles, technologies and procedures for economical detection of variation will need to be developed.

\section{CONCLUSIONS}

Understanding spatial characteristics of soil properties may help to understand soil-landscape processes and to optimize strategies for sampling and management. In this study, we assessed spatial characteristics of claypan soil properties obtained by soil sampling and compared them with $\mathrm{EC}_{\mathrm{a}}$ readings. Spatial distributions of soil properties (e.g., clay content, silt content, CEC, and Bray-1 P) were significantly different by soil depth. At the 15- to 30-cm depth, clay content, CEC, and Bray- $1 \mathrm{P}$ were positively correlated at a separation distance $\sim 40 \mathrm{~m}$ and were similar in pattern to both handheld and mobile $\mathrm{EC}_{\mathrm{a}}$ readings. For many of the properties measured, semivariance modeling did not indicate strong spatial dependence within the 30- to $150-\mathrm{m}$ range; but when $\mathrm{EC}_{\mathrm{a}}$ was used in a cross-semivariance analysis, with both handheld and mobile $\mathrm{EC}_{\mathrm{a}}$ as a secondary variable, determination of spatial characteristics of some soil properties improved.

This research showed that spatial characteristics of soil properties varied greatly by field position and by soil depth, and that spatial characteristics of some soil physical properties were similar to spatial characteristics of $\mathrm{EC}_{\mathrm{a}}$ readings. Thus spatial dependency was a function of both field location and soil sampling depth. For some soil chemical and microbiological properties, spatial patterns were not observed using our sampling strategy and analytical techniques, and therefore evaluation of their spatial characteristics would require high-density sampling. In conclusion, for properties found to have shortrange spatial dependency, traditional soil sampling will be 
impractical and thus innovative sensor-based strategies will probably be needed to capture spatial structure for characterizing variability and management planning. For this investigation on claypan soils, we conclude that describing the variation in depth of the claypan horizon is a critical step in characterizing these soils.

\section{REFERENCES}

Allison, F.E. 1973. Soil organic matter and its role in crop production. Elsevier Sci., New York.

Boots, B.N., and A. Getis. 1988. Point pattern analysis. SAGE Publ., Newbury Park, CA.

Cahn, M.D., J.W. Hummel, and B.H. Brouer. 1994. Spatial analysis of soil fertility for site-specific crop management. Soil Sci. Soc. Am. J. 58:1240-1248.

Cambardella, C.A., and D.L. Karlen. 1999. Spatial analysis of soil fertility parameters. Precis. Agric. 1:5-14.

Casida, L.E., Jr., D.A. Klein, and T. Santoro. 1964. Soil dehydrogenase activity. Soil Sci. 98:371-376.

Chang, J., D.E. Clay, C.G. Carlson, C.L. Reese, S.A. Clay, and M.M. Ellsbury. 2004. Defining yield goals and management zones to minimize yield and nitrogen and phosphorus fertilizer recommendation errors. Agron. J. 96:825-831.

Cliff, A.D., and J.K. Ord. 1973. Spatial autocorrelation. Pion Ltd., London.

Cliff, A.D., and J.K. Ord. 1981. Spatial processes - models and applications. Pion Ltd., London.

Cline, M.G. 1944. Principles of soil sampling. Soil Sci. 58:275-288.

Corwin, D.L., and S.M. Lesch. 2005. Apparent soil electrical conductivity measurements in agriculture. Comput. Electron. Agric. 46:11-43.

Davis, J.G., G.L. Malzer, P.J. Copeland, J.A. Lamb, P.C. Robert, and T.W. Bruulsema. 1996. Using yield variability to characterize spatial crop response to applied N. p. 513-519. In P.C. Robert et al(ed.) Precision Agriculture-Proc. Int. Conf., 3rd, Minneapolis. 23-26 June 1996. ASA, CSSA, and SSSA, Madison, WI.

Doolittle, J.A., K.A. Sudduth, N.R. Kitchen, and S.J. Indorante. 1994. Estimating depth to claypans using electromagnetic induction methods. J. Soil Water Conserv. 49:572-575.

Drummond, S.T., K.A. Sudduth, A. Joshi, S.J. Birrel, and N.R. Kitchen. 2003. Statistical and neural methods for site-specific yield prediction. Trans. ASAE 46:5-14.

Eghball, B., J.S. Schepers, M. Negahban, and M.R. Schlemmer. 2003. Spatial and temporal variability of soil nitrate and corn yield: Multifractal analysis. Agron. J. 95:339-346.

Ferguson, R.B., G.W. Hergert, J.S. Schepers, C.A. Gotway, J.E. Cahoon, and T.A. Peterson. 2002. Site-specific nitrogen management of irrigated maize: Yield and soil residual nitrate effects. Soil Sci. Soc. Am. J. 66:544-553.

Fraisse, C.W., K.A. Sudduth, and N.R. Kitchen. 2001. Delineation of site-specific management zones by unsupervised classification of topographic attributes and soil electrical conductivity. Trans. ASAE 44:155-166.

Ghidey, F., P.E. Blanchard, R.N. Lerch, N.R. Kitchen, E.E. Alberts, and E.J. Sadler. 2005. Measurement and prediction of herbicide transport from the corn phase of three cropping systems. J. Soil Water Conserv. 60:260-273.

Goovaerts, P. 1998. Geostatistical tools for characterizing the spatial variability of microbiological and physio-chemical soil properties. Biol. Fertil. Soils 27:315-334.

Isaacks, E.H., and R.M. Srivastava. 1989. An introduction to applied geostatistics. Oxford Univ. Press, New York.

Jamison, V.C., D.D. Smith, and J.F. Thornton. 1968. Soil and water research on a claypan soil. USDA-ARS Tech. Bull. 1379. U.S. Gov. Print. Office, Washington, DC.

Jenny, H. 1941. Factors of soil formation. McGraw-Hill, New York.

Johnson, C.K., J.W. Doran, H.R. Duke, B.J. Wienhold, K.M. Eskridge, and J.F. Shanahan. 2001. Field-scale electrical conductivity mapping for delineating soil condition. Soil Sci. Soc. Am. J. 65:1829-1837.

Johnson, C.K., K.M. Eskridge, B.J. Wienhold, J.W. Doran, G.A. Peterson, and G.W. Buchleiter. 2003. Using electrical conductivity classification and within-field variability to design field-scale research. Agron. J. 95:602-613.

Johnson, D., D. Geisinger, R. Walker, J. Newman, J. Vose, K. Elliot, and T. Ball. 1994. Soil $\mathrm{CO}_{2}$, soil respiration, and root activity in $\mathrm{CO}_{2}$-fumigated and nitrogen-fertilized ponderosa pine. Plant Soil 165:129-138.

Jung, W.K., N.R. Kitchen, K.A. Sudduth, R.J. Kremer, and P.P. Motavalli. 2005. Relationship of apparent soil electrical conductivity to claypan soil properties. Soil Sci. Soc. Am. J. 69:883-892.

Kitchen, N.R., S.T. Drummond, E.D. Lund, K.A. Sudduth, and G.W. Buchleiter. 2003. Soil electrical conductivity and topography related to yield for three contrasting soil-crop systems. Agron. J. 95: 438-449.

Kitchen, N.R., D.F. Hughes, W.W. Donald, and E.E. Alberts. 1998. Agrichemical movement in the root-zone of claypan soils: Ridge- and mulch-tillage systems compared. Soil Tillage Res. 48: 179-193.

Kitchen, N.R., C.J. Snyder, D.W. Franzen, and W.J. Wiebold. 2002. Educational needs of precision agriculture. Precis. Agric. 3:341-351.

Kitchen, N.R., K.A. Sudduth, and S.T. Drummond. 1999. Soil electrical conductivity as a crop productivity measure for claypan soils. J. Prod. Agric. 12:607-617.

Kitchen, N.R., K.A. Sudduth, D.B. Myers, R.E. Massey, E.J. Sadler, R.N. Lerch, J.W. Hummel, and H.L. Palm. 2005. Development of a conservation-oriented precision agriculture system: II. Crop production assessment and plan implementation. J. Soil Water Conserv. 60:421-430.

Kravchenko, A.N. 2003. Influence of spatial structure on accuracy of interpolation methods. Soil Sci. Soc. Am. J. 67:1564-1571.

Kravchenko, A.N., G.A. Bollero, R.A. Omonode, and D.G. Bullock. 2002. Quantitative mapping of soil drainage classes using topographical data and soil electrical conductivity. Soil Sci. Soc. Am. J. 66:235-243.

Lauzon, J.D., I.P. O'Halloran, D.J. Fallow, A.P. Bertoldi, and D. Aspinall. 2005. Spatial variability of soil test phosphorus, potassium, and $\mathrm{pH}$ of Ontario soils. Agron. J. 97:524-532.

Larson, W.E., and P.C. Robert. 1991. Farming by soil. p. 103-112. In R. Lal and F.J. Pierce (ed.) Soil management for agriculture. ASA, CSSA, and SSSA, Madison, WI.

Legendre, P., and M.J. Fortin. 1989. Spatial pattern and ecological analysis. Vegetatio 80:107-138.

Lerch, R.N., N.R. Kitchen, R.J. Kremer, W.W. Donald, E.E. Alberts, E.J. Sadler, K.A. Sudduth, D.B. Myers, and F. Ghidey. 2005. Development of a field-scale precision conservation system: I. Water and soil quality assessment. J. Soil Water Conserv. 60: 411-421.

Lund, E.D., C.D. Christy, and P.E. Drummond. 1999. Practical application of soil electrical conductivity mapping. p. 771-779. In J.V. Stafford (ed.) Precision agriculture '99. Proc. Eur. Conf. on Prec. Agric., 2nd. Sheffield Acad. Press, Sheffield, UK.

McNeill, J.D. 1992. Rapid, accurate mapping of soil salinity by electromagnetic ground conductivity meters. p. 209-229. In Advances in measurement of soil physical properties: Bringing theory into practice. SSSA Spec. Publ. 30. SSSA, Madison, WI.

Moran, P. 1948. The interpretation on statistical maps. J.R. Stat. Soc. B 10:243-251.

Myers, D.B. 2005. Soybean root distribution in claypan soils. M.S. thesis. Univ. of Missouri, Columbia.

National Soil Survey Center Staff. 1996. Soil survey laboratory methods manual. Soil Surv. Invest. Rep. 42. Version 3.0. NRCS, Lincoln, NE.

Nikiforoff, C.C., and M. Drosdoff. 1943. Genesis of claypan soil. Soil Sci. 53:459-482.

NRCS. 1995. Soil survey of Audrain County, Missouri (1995-387-974/ 00537/SCS). U.S. Gov. Print. Office, Washington, DC.

Olsen, S.R., and L.E. Sommers. 1982. Phosphorus. p. 403-430. In A.L. Page et al. (ed.) Methods of soil analysis. Part 2. 2nd ed. Agron. Monogr. 9. ASA and SSSA, Madison, WI.

Rhoades, J.D., D.L. Corwin, and S.M. Lesch. 1999. Geospatial measurements of soil electrical conductivity to assess soil salinity and diffuse salt loading from irrigation. p. 197-215. In D.L. Corwin et al. (ed.) Assessment of non-point source pollution in the vadose zone. Geophys. Monogr. 108. Am. Geophys. Union, Washington, DC.

Snedecor, G.W., and W.G. Cochran. 1989. Statistical methods. 8th ed. Iowa State Univ. Press, Ames. 
Spautz, R.E. 1998. Topsoil thickness influence on phosphorus and potassium availability and crop response. M.S. thesis. University of Missouri, Columbia.

Sudduth, K.A., S.T. Drummond, and N.R. Kitchen. 2001. Accuracy issues in electromagnetic induction sensing of soil electrical conductivity for precision agriculture. Comput. Electron. Agric. 31:239-264.
Sudduth, K.A., N.R. Kitchen, G.A. Bollero, D.G. Bullock, and W.J. Wiebold. 2003. Comparison of electromagnetic induction and direct sensing of soil electrical conductivity. Agron. J. 95:472-482.

Wang, F., C.W. Fraisse, N.R. Kitchen, and K.A. Sudduth. 2002. Sitespecific evaluation of the CROPGRO-soybean model on Missouri claypan soils. Agric. Syst. 76:985-1005. 